\title{
A Brief Account on Socio-demographic Profile of the Victims of Violent Asphyxial Deaths in Dhaka City
}

\author{
Elias B. Akber ${ }^{*}$, Sohel Mahmud ${ }^{2}$, Mushtaq Ahmad ${ }^{3}$, Ashim K. Barua ${ }^{4}$, Israt Jahan ${ }^{5}$ \\ ${ }^{1}$ Associate Professor \& Head, Department of Forensic Medicine, Army Medical College Cumilla, Cumilla Cantonment, Bangladesh \\ ${ }^{2}$ Associate Professor \& Head, Department of Forensic Medicine, Sir Salimullah Medical College, Mitford, Dhaka, Bangladesh. \\ ${ }^{3}$ Professor \& Head, Department of Forensic Medicine, Armed Forces Medical College, Dhaka Cantonment, Bangladesh \\ ${ }^{4}$ Professor, Vice-Principal \& Head, Department of Forensic Medicine \& Toxicology, Chattogram Ma O Shishu Medical College, Agrabad, \\ Chattogram, Bangladesh \\ ${ }^{5}$ Senior Lecturer, Department of Forensic Medicine, Army Medical College Cumilla, Cumilla Cantonment, Bangladesh
}

\begin{abstract}
Background: Violent asphyxial deaths are often dealt with during autopsy, and its magnitude is mentionable nowadays. Objective: To determine the frequency of cases of violent asphyxial death along with the determination of the socio-demographic variety of the victims.

Study Design: It is a cross-sectional type of descriptive study.

Place of Study: Department of Forensic Medicine of Sir Salimullah Medical College, Mitford, Dhaka, Bangladesh.

Duration: The study was conducted from January 01, 2017, to December 31, 2019.

Materials and Methods: A proforma was prepared where various data were tabulated, compiled and analyzed.

Results: 1060 cases of violent asphyxial death were encountered out of 9410 medico-legal autopsies. Male (68.67\%) predominance was evident. The age group of $20-29$ years $(44.15 \%)$ was principally affected. Maximum victims were from urban areas $(61.03 \%)$. Victims were mainly married (56.6\%) and unemployed (26.6\%). The Muslim $(81.32 \%)$ victims were mostly seen and lower class people (58.2\%) were the prime victims. Hanging $(65.84 \%)$ and drowning $(27.64 \%)$ were chiefly encountered. Conclusion: The study reflects the magnitude of violent asphyxial death and a brief picture of the socio-demographic profile of the victims.

Keywords: Violent asphyxial death, Hanging, Strangulation, Drowning, Autopsy.

Int J Eth Trauma Victimology (2021). DOI: 10.18099/ijetv.v7i02.6
\end{abstract}

\section{INTRODUCTION}

The term "Asphyxia' has been accepted in the true medicolegal sense for many a year around the globe. ${ }^{1}$ It is a Greek term that means pulselessness. ${ }^{2}$ But in Forensic Parlance, it is meant by "Interference with oxygenation". ${ }^{3}$ Mechanical asphyxia is a broad term in which enough external pressure is applied to the neck, chest, or other areas of the body, or the body is positioned in such a way that respiration becomes difficult or impossible. ${ }^{4}$ Commonly encountered violent asphyxial deaths include hanging, ligature strangulation, manual strangulation or throttling, smothering, drowning, traumatic asphyxia, and choking. Among these, hanging is one of the prime methods to commit suicide ${ }^{5-11}$ Hanging is invariably thought to be suicidal except accidental hanging in autoerotic deaths, homicidal hanging in case of lynching, and judicial hanging. In England and Wales, hanging constitutes about 2000 deaths each year and is considered the most common method of suicide. ${ }^{12}$ Hanging is the second most common technique to commit suicide as per the report published in Canada. ${ }^{13}$ Death due to strangulation is considered homicidal all the time, but it may be accidental. ${ }^{14-18}$ Since Bangladesh is a land of rivers and there are plenty of lakes, ponds, and wells, a large seacoast,
Corresponding Author: Elias Bin Akber, Associate Professor \& Head, Department of Forensic Medicine, Army Medical College Cumilla, Cumilla Cantonment, Bangladesh, Mobile : +88 01840444434, e-mail: eliasbinakber@gmail.com

How to cite this article: Akber EB, Mahmud S, Ahmad M, Barua AK, Jahan I. A Brief Account on Socio-demographic Profile of the victims of Violent Asphyxial Deaths in Dhaka City. Int J Eth Trauma Victimology. 2021;7(2):30-34.

Source of support: Nil

Conflict of interest: None

Received: 07/07/2021;

Accepted:24/11/2021;

Received in revised form: $12 / 11 / 2021$; Published: 20/01/2022

drowning cases are often encountered at autopsy. Based on a global burden of disease (GBD) study conducted by WHO in 2010, global mortality due to drowning is estimated to be $7 \%$ of all asphyxial deaths. They also estimated the annual global incidence of death in drowning to be $4,00,000 \cdot{ }^{19-23}$ The cases of smothering are very rarely dealt with in Bangladesh. Postmortem findings are often missed during autopsy if a soft pillow or a soft cloth is used for this purpose. Careful history taking, crime scene investigation, and careful examination 
can solve this problem and may preserve justice. ${ }^{24}$ Cases of traumatic asphyxia are not often found in Bangladesh.

In most cases, traumatic asphyxia is accidental. ${ }^{25}$ Literature in this respect is of unmentionable number here in Bangladesh. Henceforth, this study aimed to ascertain the frequency of cases of violent asphyxial death in Sir Salimullah Medical College Morgue House, Dhaka from socio-demographic viewpoints.

\section{Aims and Овjectives}

- The study was done to assess the impact of violent asphyxia to bring about death along with other unnatural causes

- To determine the socio-demographic variety of the victims.

\section{Materials and Methods}

This study was done from Jan 2017 to Dec 2019 at Sir Salimullah Medical College Mortuary Dhaka in which the study revealed 1060 cases of violent asphyxial death out of the total 9410 medico-legal autopsies. A proforma was prepared and findings were written down in various tables. Epidemiological data, including age, sex, religion, dwelling place, marital status, occupation, and family history, were collected from the police inquest reports and information gathered from interviews with the relatives of the deceased. After that, these variables were tabulated, assembled, and scrutinized.

\section{Observations and Results}

Table 1 shows a gradual yearly increase in the total number of cases of violent asphyxial death which denotes 303 cases (10.84\%) of the total 2794 autopsies in 2017 followed by 336 cases (10.72\%) of the total 3133 autopsies in 2018 and 421 cases $(12.08 \%)$ of the total 3483 autopsies in the year 2019. Thus, this study revealed a total of 1060 cases of violent asphyxial death, comprising $11.26 \%$ of the total 9410 autopsies.

Table 2 shows a total of $728(68.67 \%)$ male victims, which outnumbered the females (332 victims/31.32\%) out of the total 1060 cases of violent asphyxia.

Table 1: Year-wise distribution of cases of violent asphyxial death

\begin{tabular}{llll}
\hline Year & $\begin{array}{l}\text { Total no. of } \\
\text { the autopsy } \\
\text { performed }\end{array}$ & $\begin{array}{l}\text { Frequency of } \\
\text { cases of violent } \\
\text { asphyxial death }\end{array}$ & $\begin{array}{l}\text { Percentage } \\
\text { (\%) }\end{array}$ \\
\hline 2017 & 2794 & 303 & 10.84 \\
2018 & 3133 & 336 & 10.72 \\
2019 & 3483 & 421 & 12.08 \\
Total & 9410 & 1060 & 11.26 \\
\hline
\end{tabular}

Table 2: Sex-wise distribution of cases of violent asphyxial death $(n=1060)$

\begin{tabular}{lll}
\hline Sex & Frequency & Percentage (\%) \\
\hline Male & 728 & 68.67 \\
Female & 332 & 31.32 \\
Transgender & 0 & 0 \\
Total & 1060 & 100 \\
\hline
\end{tabular}

Table 3 indicates the most affected age group was 20-29 years in 468 cases $(44.15 \%)$ followed by $30-39$ years in 244 cases $(23.01 \%)$, $40-49$ years in 124 cases $(11.69 \%), 50-59$ years in 113 cases (10.66\%), 10-19 years in 107 cases (10.09\%), $0-9$ years in 3 cases $(0.28 \%)$ and $>60$ years only in 1 case accounting for $0.09 \%$ of the total.

Table 4 shows that the majority of the victims were from urban areas i.e., in 647 cases (61.03\%) followed by rural in 228 cases $(21.50 \%)$, sub-urban in 178 cases $(16.79 \%)$, and 7 victims were unknown, comprising $0.66 \%$ of the total.

Table 5 Manifests that among 728 male victims 387 (53.15\%) were married, 336 (46.15\%) were unmarried, and 5 victims $(0.68 \%)$ were unknown. On the other hand, among 332 female victims, $213(64.15 \%)$ were married, followed by unmarried $117(35.24 \%)$ and unknown 2(0.6\%). Wherefore, this study revealed a total of $600(56.60 \%)$ married victims followed by $453(42.73 \%)$ unmarried and only $7(0.66 \%)$ unknown victims out of the total 1060 cases of violent asphyxial death.

Table 6 reveals that Muslims were on top of the list concerning religion which means in 862 cases $(81.32 \%)$ followed by Hindus in 132 cases (12.45\%) and Christians in 5 cases $(0.47 \%)$. There were $7(0.66 \%)$, unknown victims, as well.

Table 7 shows the dominance of lower-class people as far as socio-economic class is concerned that means in 617 cases (58.20\%) followed by the middle class in 239 cases $(22.54 \%)$ and upper class in 197 cases (18.58\%).

Table 8: indicates that maximum victims were unemployed which means in 282 cases $(26.60 \%)$ followed by housewives in 276 cases (26.03\%), students in 192 cases (18.11\%), day laborers in 188 cases $(17.73 \%)$, service holders in 64 cases $(6.03 \%)$, businessmen in 33 cases $(3.11 \%)$, farmers in 16 cases $(1.50 \%)$ and only 2 victims $(0.18 \%)$ who were retired from their job.

Table 3: Age-wise distribution of cases of violent asphyxial death $(\mathrm{n}=1060)$

\begin{tabular}{lll}
\hline Age in years & $\begin{array}{l}\text { No. of cases of violent } \\
\text { asphyxial death }\end{array}$ & Percentage(\%) \\
\hline $0-9$ & 3 & 0.28 \\
$10-19$ & 107 & 10.09 \\
$20-29$ & 468 & 44.15 \\
$30-39$ & 244 & 23.01 \\
$40-49$ & 124 & 11.69 \\
$50-59$ & 113 & 10.66 \\
$>60$ & 1 & 0.09 \\
Total & 1060 & 100 \\
\hline
\end{tabular}

Table 4: Distribution of cases of violent asphyxial death in relation to dwelling place $(n=1060)$

\begin{tabular}{lll}
\hline Dwelling place & Frequency & Percentage (\%) \\
\hline Urban & 647 & 61.03 \\
Rural & 228 & 21.50 \\
Sub-urban & 178 & 16.79 \\
Unknown & 7 & 0.66 \\
Total & 1060 & 100 \\
\hline
\end{tabular}


A Brief Account on Socio-demographic Profile of the Victims of Violent Asphyxial Deaths in Dhaka City

Table 5: Distribution of cases of violent asphyxial death based on marital status ( $n=1060)$

\begin{tabular}{|c|c|c|c|c|c|c|}
\hline \multirow[b]{2}{*}{ Marital Status } & \multicolumn{2}{|c|}{ Male } & \multicolumn{2}{|c|}{ Female } & \multicolumn{2}{|c|}{ Total } \\
\hline & No. & $\%$ & No. & $\%$ & No. & $\%$ \\
\hline Married & 347 & 53.15 & 213 & 64.15 & 600 & 56.60 \\
\hline Unmarried & 336 & 46.15 & 117 & 35.24 & 453 & 42.73 \\
\hline Unknown & 5 & 0.68 & 2 & 0.6 & 7 & 0.66 \\
\hline Total & 728 & 100 & 332 & 100 & 1060 & 100 \\
\hline
\end{tabular}

Table 6: Distribution of cases of violent asphyxial death according to religion $(n=1060)$

\begin{tabular}{lll}
\hline Religion & Frequency & Percentage (\%) \\
\hline Muslim & 862 & 81.32 \\
Hindu & 132 & 12.45 \\
Christian & 5 & 0.47 \\
Buddhist & 0 & 0 \\
Unknown & 7 & 0.66 \\
Total & 1060 & 100 \\
\hline
\end{tabular}

Table 8: Distribution of cases of violent asphyxial death according to occupation ( $n=1060)$

\begin{tabular}{lll}
\hline Occupation & Frequency & Percentage (\%) \\
\hline Unemployed & 282 & 26.60 \\
Housewives & 276 & 26.03 \\
Students & 192 & 18.11 \\
Day Laborers & 188 & 17.73 \\
Employed (service) & 64 & 6.03 \\
Businessmen & 33 & 3.11 \\
Farmers & 16 & 1.50 \\
Unknown & 7 & 0.66 \\
Retired persons & 2 & 0.18 \\
Total & 1060 & 100 \\
\hline
\end{tabular}

Table 9 shows that hanging was mostly encountered among other cases of violent asphyxial death which means hanging was in 698 cases $(65.84 \%)$ followed by drowning in 293 cases $(27.64 \%)$, traumatic asphyxia in 34 cases $(3.20 \%)$, strangulation in 19 cases $(1.79 \%)$, throttling in 14 cases $(1.32 \%)$ and smothering only in 2 cases accounting for $0.18 \%$ of the total.

\section{Discussion}

Table 1: This study revealed 1060 cases (11.26\%) of violent asphyxial death. Almost indistinguishable observations were drawn by Kumar et al. ${ }^{26}(10.5 \%)$, Murty et al. ${ }^{27}$ (10\%), Tirmizi et $a l .{ }^{28}(7.08 \%)$, Arif et al. ${ }^{29}(5.9 \%)$, Patel et al. ${ }^{30}(5.63 \%)$, Amandeep et al. ${ }^{31}$ (5.26\%) and Sharma et al. ${ }^{32}$ (5\%). On the other hand, in studies conducted by Azmac D et al. ${ }^{33}$ and Reddy SP et al., ${ }^{34}$ the occurrences were $15.7 \%$ and $19.7 \%$, respectively.

Table 2: Male predominance was observed in this study. Similar impressions were obtained from the study done by Patel et $a l .{ }^{30}$ Males were the most common victims in other studies done by Chaurasia et al. ${ }^{35}$ (Males-60.89\% \& females- 39.11\%), Vadgama et al. ${ }^{36}$ (Males-64\% \& females-36\%), Ahmad et al. ${ }^{37}$
Table 7: Distribution of cases of violent asphyxial death concerning socio-economic status $(n=1060)$

\begin{tabular}{lll}
\hline Social Class & Frequency & Percentage (\%) \\
\hline Lower class & 617 & 58.20 \\
Middle class & 239 & 22.54 \\
Upper class & 197 & 18.58 \\
Unknown & 7 & 0.66 \\
Total & 1060 & 100 \\
\hline
\end{tabular}

Table 9: Distribution of cases of violent asphyxial death on the basis of type of death $(n=1060)$

\begin{tabular}{lll}
\hline Type of Death & Frequency & Percentage (\%) \\
\hline Hanging & 698 & 65.84 \\
Drowning & 293 & 27.64 \\
Traumatic Asphyxia & 34 & 3.20 \\
Strangulation & 19 & 1.79 \\
Throttling & 14 & 1.32 \\
Smothering & 2 & 0.18 \\
Total & 1060 & 100 \\
\hline
\end{tabular}

(Males-61.9\% \& females-38.1\%) and Akber et al. ${ }^{38}$ (Males$54.07 \%$ \& females-45.92\%).

Table 3: The age group of 20-29 years was most affected. Similar findings were found from other studies done such as Ghadge et ll $^{39}$ and Arora. et al. ${ }^{40}$

Table 4: Maximum victims were from urban areas. Studies showing similar pictures include Chauhan et al. ${ }^{41}$ (Urban $70.2 \%$, sub-urban-19.85\% and rural-9.89\%), Rawat et al. ${ }^{42}$ (Urban-72.28\% and rural-27.72\%). Some other studies reflected dissimilar pictures where the victims were more in rural areas than urban areas which include Singh et $\mathrm{al}^{43}$ (Rural-51.6\% \& urban-48.4\%), Santosh CS et al. ${ }^{44}$ (Rural-51.14\% \& urban$44.86 \%$ ) and Gupta et al. ${ }^{45}$ (Rural-43.75\% \& urban-41.56\%)

Table 5: Both male and female victims were from the married group in this study. In contrast, these findings were almost similar to the study done by Kumar et $\mathrm{al}^{26}$ in which there were $63.9 \%$ married victims as compared to $36.1 \%$ victims who were unmarried. Waghmare et al. ${ }^{46}$ revealed $68.33 \%$ victims who were married as compared to $25 \%$ unmarried victims, and Ahmad et al. ${ }^{37}$ revealed 51 (57.3\%) married and 38 (42.7\%) unmarried victims.

Table 6: In this study, Muslims were the predominant victims. A similar study revealed a completely different picture as reported by Sharma et al. ${ }^{32}$ in which predominant victims 
were Hindus (98.6\%) and Mohanty et al. ${ }^{47}$ also revealed the dominance of Hindu victims (93.5\%).

Table 7: People of lower socioeconomic status were the prime victims in this study. A similar study conducted by Singh et al. ${ }^{48}$ revealed $215(98.17 \%)$ victims were also from the lower class followed by the middle class ( 3 cases/1.36\%) and upper class ( 1 case $/ 0.45 \%)$.

Table 8: Maximum victims were from the group of unemployed and housewives as per observation from this study. A similar study was done by Majumder et al. ${ }^{49}$ in which there were $25.8 \%$ students, $21.3 \%$ farmers and $11.3 \%$ service holders.

Table 9: In this study, cases of hanging and drowning were mostly encountered. A study conducted by Singh et al. ${ }^{48}$ revealed hanging in $60.27 \%$ followed by drowning (19.63\%) and strangulation (14.61\%). Similar pictures were observed in a study conducted by Gurudut et al. ${ }^{50}$ Cases of smothering are rarely dealt with in Bangladesh. A study, conducted in Ghana revealed that cases of smothering accounted for $0.158 \%$ of the total 635 cases of unnatural death in the central region of Ghana. ${ }^{51,52}$ Another study was conducted in Varanasi, India in which there were 33 cases of traumatic asphyxia among the other cases of violent asphyxial death. ${ }^{53}$

\section{Acknowledgment}

I am grateful to all the faculty, staff and mortuary assistants of the Department of Forensic Medicine of Sir Salimullah Medical College, Mitford, Dhaka. I would like to thank Dr Sohel Mahmud, Head of the Department of Forensic Medicine of Sir Salimullah Medical College for his continuous and tremendous support in conducting this study. All the authors contributed equally during data collection, data analysis, and editing of the manuscript.

\section{Conclusion}

In the light of the above, this study concluded that hanging and drowning were mostly encountered among all other violent asphyxia. Hanging was observed to be the most chosen means to commit suicide. Furthermore, people with emotional instability and suicidal tendencies need counseling and psychiatric consultations to prevent suicide. Drowning contributed mainly to accidental deaths. Carelessness, hurriedness and heavy rushes in launches, steamers and boats on the part of the passengers during the festival time are identified causes of accidental drowning in Bangladesh. Electronic and print media can play a vital role in initiating awareness among mass people. Law enforcing authority and Bangladesh Inland Water Transport Authority (BIWTA) have to monitor the movement of the water transports vigorously, particularly during major festivals, to cut down and prevent further incidences of accidental drowning from the country.

\section{REFERENCES}

1. Mahanta P. Modern Textbook of Forensic Medicine and Toxicology, $1^{\text {st }}$ ed. Jaypee Brothers Medical Publishers (P) Ltd, 4838/24, Ansari Road, Daryaganj, New Delhi 110 002, India. 2014:340-360
2. Seth S. Review of Forensic Medicine, $7^{\text {th }}$ ed. Peepee Publishers and Distributors (P) Ltd, 7/31 First floor, Ansari Road, Daryaganj, New Delhi 110 034, India. 2018:117-121.

3. Apurba N. Principles of forensic medicine. New Central Agency (P) Ltd. 1995:577-578.

4. Mallik CC. A Short Textbook of Medical Jurisprudence, $3^{\text {rd }}$ ed. The New Book Stall, 5/1 Ramnath Mazumdar Street, Calcutta 700 009, India, 1993:181-271.

5. Goktas S, Metintas S. Suicide mortality trends by age, gender and method in Turkey, 2002-2015, Turk J Public Health, 2019;17(2):195-206.

6. Yoshioka E, Hanley S, Kawanishi Y, Saijo Y. Time trends in method-specific suicide rates in Japan, 1990-2011. Epidemiol Psych Sci, 2016;25(1);:58-68.

7. Vichi M, Masocco M, Pompili M, Lester D, Tatarelli R, Vanacore N. Suicide mortality in Italy from 1980-2002. Psych Res, 2010, 175(1):89-97

8. Lotrakul M. Suicide in Thailand during the period 1998-2003, Psych \& Clin Neurosciences, 2006;60(1):90-95.

9. Starkuviene S, Kalediene R, Petrauskiene J. Epidemic of suicide by hanging in Lithuania: does socio-demographic status matter? Public Health, 2006;120(8);769-775.

10. Gunnell D, Bennewith O, Hawton K, Simkin S, Kapun N. The epidemiology and prevention of suicide by hanging: a systematic review. Int. J Epidemiol, 2005;34(2);433-442.

11. Lotrakul M. Suicide in the north of Thailand, J Med Assoc Thai, July 2005; 88(7):944-9480.

12. Bennewith O, Gunnel D, Kapur N, Turnbull P, Simkin S, Sutton L. et al, suicide by hanging: multicentre study based on coroner's records in England. The Brit J Psychiatry. 2005;186:260-261.

13. Hanging New World encyclopedia [Online] 2009 [Cited 2009 Nov 11]. Available from http://www.newworldencyclopedia. org/entry/hanging.

14. Williamson F, Collins S, Dehn A, Doig S. Vascular injury is an infrequent finding following non-fatal strangulation in two Australian trauma centres. Emerg Med Australasia, Sept 2021; 31(2):476-483.

15. Bichard H, Byrne C, Saville CWN, Coetzer R. The neurophysiological outcomes of non-fatal strangulation in domestic and sexual violence: A systematic review. Neuropsychological Rehabilitation - An Int J. Taylor \& Francis, Jan 2021;48(1):606-617.

16. Douglas H, Fitgerald R. Proving non-fatal strangulation in family violence cases: A case study on the criminalization of family violence. The Int J Evi \& Proof, 2021;25(4);348-356.

17. Boos JD. Non-fatal strangulation: Hidden injuries, hidden risks. Emerg Med Australasia, June 2019, 31(3);302-308.

18. Monahan K, Purusthotham A, Biegon A. Neurological implications of non-fatal strangulation and intimate partner violence. Future Neurol, 2019; 14(3):532-539.

19. Meddings DR, Scarr JP, Larson K, Vaughan J, Krug EG. Drowning prevention: turning the tide on a leading killer. THE LANCET Public Health, Sept 2021;6(9);692-695.

20. Koon W, Peden A, Lawes JC, Brander RW. Coastal drowning: A scoping review of burden, risk factors and prevention strategies. PLOS ONE, Feb 2021, 16(2):238-245.

21. Judy BA. Drowning remains a leading Cause of Injury Related Deaths in Children, The Am J MCN, Dec 2019;44(6);359.

22. Peden AE, Franklin RC, Clemens T. Exploring the burden of fatal drowning and data characteristics in three high income countries: Australia, Canada and New Zealand, 2019;19(1): 326-332 
23. Beeck EFV, Branche CM, Szpilman D, Modell JH, Bierens JJLM, A new definition of drowning: towards documentation and prevention of a global public health problem, Bulletin of the World Health Organization, 2005;83(11);853-856.

24. Singh OG, Lepcha C, Serma PC. Fatal accidental smothering : A Case Report. J Punjab Acad. Forensic Med Toxicol, 2011;11(1):42-43.

25. Richards CE, Wallis DN. Asphyxiation: a review. Trauma, 2005; 7:37-45.

26. Ajay Kumar S, Chandan V, Rudresh YC, Govindaraju HC, Gouda S. Study of violent asphyxia deaths in Chitradurga district of Karnataka IJBAR, 2013;4(12):868-871.

27. Murty OP, Agnihotri AK. Homicidal Deaths in South Delhi. J Ind Acad Forensic Med, 2000;22:9-11.

28. Tirmizi SZ, Mirza FH, Paryar HA. Medico-legal investigation of violent asphyxia deaths - an autopsy based study. J Dow Uni Health Sci, 2012;6:86-90.

29. Arif M. Ligature mark on the neck; How elucidative? Professional Med J, 2015;22:798-803.

30. Patel AP, Bhoot RR, Patel DJ, Patel KA. Study of violent asphyxial death. International journal of medical toxicology and forensic medicine. 2013;3(2):48-57.

31. Singh A. A study of demographic variables of violent asphyxia death: Journal of Punjab Acad of Forensic Med and Toxicol, 2003;3:32-34.

32. Sharma BR, Harish D, Sharma A, Sharma S, Singh H. Injuries to neck structures in deaths due to constriction of neck, with a special reference to hanging. J Forensic Leg Med, 2008;15: 298-305.

33. Azmak D. Asphyxial Deaths: a retrospective study and review of the literature. Am J Forensic Med Pathol, 2006;(2):134-144.

34. Reddy SP, Kumar P, Rudramurthy. Asphyxial deaths at district hospital, Tumkur a retrospective study. J Indian Acad Forensic Med, 2012;34(2):146-147.

35. Chaurasia N, Pandey SK, Mishra A. An Epidemiological Study of Violent Asphyxial Death in Varanasi Region (India) a Killing Tool. J Forensic Res, 2012;10(6):174.

36. Vadgama DK, Manvar PJ, Varu PR, Vaghela RD, Mashru RK. Study of asphyxial deaths in Rajkot Region. Indian Journal of Forensic \& Com Med, Oct-Dec 2016;3(4):254-256.

37. Ahmad M, Rahman FN, Hussain MA, Chowdhury MH, Yasmeen BHN. A medico-legal study of hanging cases at Dhaka Medical College. IMCH J, 2015;7(1):110-114.

38. Akber EB, Forhad AJ, Karim F, Islam MS, Jahan I. Hanging - A Common Method to Commit Suicide - A Retrospective Post-
Mortem Study. Dhaka Community Medical College Journal, 2014;3(1):10-13.

39. Ghadge MR, Samel DR, Kulkarni DV, Pate R. Sociodemographic factors in mechanical asphyxia deaths in Thane region, Maharashtra, India. Int. J Res Med Sci, 2016;4:4078-4083.

40. Arora S. Profile of unnatural female deaths in Jammu region - an autopsy based study. IJFMT, 2016;10:25-29.

41. Chauhan S. Suicidal cases surge $45 \%$ in 3 years in HP. Hindustan Times, Shimla, 2015

42. Rawat V, Rodrigues EJ. Medico-legal study of hanging cases in North Goa. Int J Forensic Sci. Pathol. 2015;3(5):110-118.

43. Singh B, Ghosh M, Sangal A, Srivastava AK. A Postmortem medicolegal study of violent asphyxial deaths-An autopsy based study. Int Arch BioMed Clin Res. 2017 Apr;3(2):104-107.

44. Santosh CS, Nawaz B. Pattern of suicidal deaths at district hospital Davangere, a cross- sectional study. J Indian Acad Med, 2013;35(3):233-235.

45. Gupta VP, Mahanta P. A Study of Asphyxial Death Cases in Medico-legal Autopsy. IJHRMLP, 2016;2(2):86-89.

46. Waghmare PB, Chikhalkar BG, Nandakar SD. Analysis of Asphyxial death due to hanging. J Indian Acad Forensic Med, 2014;3(6):4.

47. Mohanty S, Sethi A, Patnaik KK, Mishra A. Sociodemographic study of suicide among the people in Sothern town Berhampur of Odisha State (India). Austin J Forensic Science Criminol, 2014;1(2):1-6.

48. Singh B, Ghosh M, Sangal A, Srivastava AK. A Post-Mortem Medico-Legal Study of Violent Asphyxial Deaths-An Autopsy Based Study. Int Arch. Of Biomedical and Clin Res. 2017;3(2):104-107.

49. Majumder BC. Study of Violent Asphyxial Deaths. JIAFM, 2002;24(2):8-10.

50. Gurudut KS, Ajaykumar S, Hareesh SG. Analysis of Fatal Cases of Mechanical Asphyxia at Belgaun, Karnataka. Journal of Forensic Med and Toxicol, 2011;28:51-53.

51. Menda D, Nawa M, Sichinga K. Community Causes of Death in the Central Region of Ghana, the Missing piece in Mortality Data. Hindawi Advances in Public Health, 2020;33(1): 249-254.

52. Devassy S, Subramanian V, Subramanian A. Hypertensive Fall Turning into a Homicidal Smothering. J Foe Path, 2020;5(1);1-3.

53. Khalkho SK, Pathak MK. Death due to Traumatic Asphyxia in Varanasi Region, India. Int J Med. Tox \& Forensic Med, 2019, 9(2);51-55. 